\title{
An Institution, Its People and Its Documents: The Russian Consulate in Jerusalem through the Foreign Policy Archive of the Russian Empire, 1858-1914
}

\author{
Irina Mironenko-Marenkova and Kirill Vakh
}

The founding of the Russian Consulate (1858-1914), which would play a significant role in shaping contemporary Jerusalem, contributed to the construction of the first district for Russian pilgrims outside of the Old City walls. At that time, the Russian representative office, which dealt with complex ecclesiastic and humanitarian issues, was situated in the diplomatic circle of European missions in the Holy City.

The history of the Russian presence in the Holy Land has been recently reintroduced into the Russian research field. ${ }^{1}$ Research has focused on ecclesiastic and diplomatic aspects in Russian foreign policy in the Christian Orient, ${ }^{2}$ and

1 The topic of the Russian presence in Palestine was examined in the Russian research literature of the second half of the nineteenth century in parallel with the development of diplomatic and philanthropic institutions. Soviet historians had no interest in such issues; at that time, however, important research appeared outside Russia. See Theofanis G. Stavrou, Russian Interests in Palestine, 1882-1914: A Study of Religious and Educational Enterprise (Thessaloniki: Institute for Balkan Studies, 1963); Theofanis G. Stavrou and Peter Weisensel, Russian Travelers to the Orthodox East from the Twelfth to the Twentieth Century (Columbus: Slavica, 1986); Derek Hopwood, The Russian Presence in Syria and Palestine, 1843-1914: Church and Politics in the Near East (Oxford: Clarendon Press, 1969); Joseph N. Hajjar, L'Europe et les destinées du Proche-Orient, 3 vols. (Damascus: Dar Tlass, 1988). In the twenty-first century, the topic got a new impetus in Russia under the influence of the growing Russian ecclesiastical presence in Palestine. See, for instance, Alexandr Alexeevich Kornilov, "Sozdanie i operativnye zadachi rossijskogo konsul'stva v Ierusalime, 1858-1859" [Creation and strategic goals of the Russian consulate in Jerusalem, 1858-59], accessed January 12, 2018, http://www .ippo.ru/old/history/do/kons/2/index.html; Kirill Vakh, "Osnovanie rossijskogo konsul'stva v Ierusalime v svete novykh arkhivnykh dokumentov" [Foundation of the Russian consulate in Jerusalem from the viewpoint of new documents], Vostochnyj arkhiv 31, no. 1 (2015).

2 Boris Fedorovich Iamilinets, Rossiia i Palestina. Otcherk politicheskikh i kul'turno-religioznykh otnoshenii. XIX-nachalo XXv. [Russia and Palestine: essay on political, cultural and religious relations, 19th-early 2oth centuries] (Moscow: Institut Vostokovedenia RAN; St. Petersburg:

(C) IRINA MIRONENKO-MARENKOVA AND KIRILL VAKH, 2018 | DOI:10.1163/9789004375741_014 This is an open access chapter distributed under the terms of the prevailing CC-BY-NC-ND License at the time of publication. 
there are new publications and surveys of archive documents on the Russian presence in Palestine. ${ }^{3}$ However, there are still no comprehensive works on the activity of the Russian consulate in Jerusalem, or on the consuls themselves.

The archive of the Russian Consulate in Jerusalem has not been preserved as an entity of documents. Until now, scholars could access single consular reports only - those kept in copies or in originals in some Russian archives. We need to detect, systematize, and describe the main body of diplomatic documents issued by the Russian consulate in Jerusalem during its existence. Our research, which aims at revealing the contents of the consular archive based on the documents preserved in other archives, intends to be a step in this direction. This study examines the reasons and circumstances behind the foundation of the Russian Consulate in Jerusalem, and outlines the responsibilities entrusted to Russian consuls there. We then characterize the Russian Consulate archive collections and discuss a range of issues they present.

Letnii Sad, 2003); Iakushev Mikhail Il'ich, Antiokhijskii I Ierusalimskii Patriarkhat v politike Rossiiskoi imperii, 1830-natchalo XX v. [The patriarchates of Antioch and Jerusalem in the politics of the Russian Empire, 1830-early 2oth century] (Moscow: Indrik, 2013); Irina Iur'evna Smirnova, Mitropolit Filaret i Pravoslavnyi Vostok: iz istorii mezhtzerkovnykh sviazei [Metropolitan Filaret and Orthodox Orient: a history of interchurch relations] (Moscow: Rosspen, 2014); Jevguenii Mikhailovich Kopot', “Kvoprosu ob interpretatsii greko-arabskogo protivostoiania i vlianii Rossii v Antiokhiiskom patriarchate vo vtoroi polovine XIX v.: po materialam AVPRI" [An interpretation of the confrontation between Greeks and Arabs and the Russian influence in the patriarchate of Antioch in the second half of the 19th century: documents from the Archive of Foreign Policy of the Russian Empire (AFPRI)], Vestnik Moskovskogo Universiteta 13, no. 3 (2011).

3 Theophilus C. Prousis, "Archival Gleanings on Russian Trade and Consulates in the Near East," Balkanistica no. 17. (2004); Prousis, "A Guide to AVPRI Materials on Russian Consuls and Commerce in the Near East," Modern Greek Studies Yearbook 16-17 (2000/2001); Prousis, "AVPR (Arkhiv Vneshnei Politiki Rossii) and the Orthodox East," Modern Greek Studies Yearbook 12-13 (1996/1997): 473; Nikolai Nikolaevich Lisovoi, ed., Rossiia v Sviatoi Zemle. Dokumenty i materialy [Russia in the Holy Land: documents and materials], 2 vols. (Moscow: Mezhdunarodnye otnoshenia, 200o); Lisovoi, ed., Rossiia $v$ Sviatoi Zemle. Dokumenty i materialy [Russia in the Holy Land: documents and materials], Vol. 3 (Moscow: Indrik, 2015); Olga Nikolaevna Kopylova, ed., Rossiia i Khristianskii Vostok v dokumentakh Gosudarstvennogo arkhiva Rossijskoj Federatsii, XIX-XX vv. Annotirovannyj ukazatel' del i dokumentov [Russia and the Christian Orient: documents of the State Archive of the Russian Federation, 19th2oth centuries; annotated index of dossiers and documents] (Moscow: Indrik, 2015). 


\section{Establishing the Russian Consulate in Jerusalem: A Diplomatic and Ecclesiastic Challenge}

The Russian Consulate in Jerusalem was founded in 1858 , soon after the Crimean War (1853-56). At that time, various countries had already established missions in Jerusalem: Britain (1838), Prussia (1842), France and Sardinia (1843), the United States of America (1844), Austria (1849), and Spain (1854) all had active missions in the Holy City. A possible explanation for the Russian "delay" is that, for a long time, St. Petersburg had perceived Palestine as a strictly ecclesiastic territory. Until the Crimean War, the Greek Orthodox Patriarchate of Jerusalem dealt with Russian pilgrims, in agreement with the Russian authorities. In exchange, the Russian Embassy in Constantinople provided diplomatic and political support for the patriarchate. In fact, since 1820, the only Russian diplomatic mission in Palestine had been the vice-consulate in Jaffa. From 1838, Jerusalem was under the jurisdiction of the Russian Consulate General in Beirut, which was responsible for all of Palestine. In 1847 , St. Petersburg sent the Russian Ecclesiastical Mission (REM) to the Holy City to control Russian pilgrims, and to provide a direct channel of ecclesiastic communication between the Russian Synod and the Greek Orthodox Patriarchate in Jerusalem. The REM suspended its activities during the Crimean War, and in 1857 it was revived under the guidance of Bishop Kirill Naumov (1857-63), who replaced Archimandrite Porfyrii Uspenskii $(1847-54) .{ }^{4}$

According to a project of the Minister of Foreign Affairs, Alexander Mikhailovich Gorchakov (1856-82), the objective of the REM under Bishop Kirill was to serve Russia's ecclesiastic and diplomatic interests in Palestine. In practice, this meant that the mission had a political role to play. Since there was still no consulate in Jerusalem, Bishop Kirill received instructions and tasks from three different sources: the Minister of Foreign Affairs, the Director of the Asian Department of the Russian Ministry of Foreign Affairs, and the Russian ambassador in Constantinople. The head of the REM reported to each of the three bodies, while the consul general in Beirut was instructed to provide him with regular support and assistance. As an ecclesiastic institution, the mission was subordinate to the Synod of the Russian Church. From 1857 until 1862, however, it was under the control of the Russian Ministry of Foreign Affairs.

Surprisingly, the establishment of the Russian Consulate in Jerusalem was not a result of the interests of the Ministry of Foreign Affairs. At its head, Gorchakov believed that Russia needed an ecclesiastic mission rather than a

4 See the chapter by Lora Gerd and Yann Potin, "Foreign Affairs through Private Papers: Bishop Porfyrii Uspenskii and his Jerusalem Archives, 1842-186o," in this volume. 
political mission in the East. ${ }^{5}$ The foundation of the consulate was supported by the Naval Ministry, the Russian Steam Navigation and Trading Company (ROPIT), created in 1856, and by Kyrillos II, the Greek Orthodox Patriarch of Jerusalem. Kyrillos II was concerned about the French interest in repairing the cupola of the Holy Sepulchre, which they had expressed during the Crimean War. The patriarch feared that the French initiative could lead to a revision of the Status Quo of property rights on the parts of the Holy Sepulchre. ${ }^{6}$ Kyrillos II supported the establishment of a permanent consulate in Jerusalem since he did not want to appeal to Protestants either (Britain or Prussia). The Greek government did not have enough power or legal rights to get involved on equal terms with France and, therefore, a stronger Russian presence in Jerusalem best suited Kyrillos II's agenda. He clearly preferred Orthodox Russia to Catholic France. In a discussion with the head of the REM, Bishop Kirill, which took place in Constantinople in late January $185^{8}$, the patriarch noted that the mission "could not replace a constant consulate in Jerusalem, and that made its opening only more urgent."7 In a message to Gorchakov, A. P. Butenev, the Russian envoy in Constantinople, confirmed that "the Patriarch of Jerusalem eagerly recommended founding a Russian Consulate in the Holy City".

According to Gorchakov, the REM was the unique and authentic ecclesiastic and diplomatic mission of the Ministry of Foreign Affairs in Palestine. Other diplomats could be sent to support the mission, but the minister believed that any Russian structure in Jerusalem, even a consular one, should be subordinate to the head of the REM. Gorchakov's divisive opinion was the root cause of long-lasting competition between the consulate and the REM. Thus, it was at his own risk that Butenev, under the pressure of the patriarch, and possibly with the approval of Bishop Kirill, ordered N. S. Marabutti, the vice-consul in Jaffa, to move to Jerusalem and "to remain at the disposal of our Ecclesiastical mission ... until further notice." ${ }^{9}$ Kyrillos II who wanted to see a Greek in this position, recommended Marabutti to Butenev as a suitable candidate.

5 Fedor Ivanovich Titov, Preosviatchennyj Kirill Naumov, episkop Melitopol'skii, byvchii nastoiatel' Russkoi Dukhovnoi Missii v Ierusalime [The most reverend Kirill Naumov, bishop of Melitopol, ex-chief of the Russian ecclesiastical mission in Jerusalem] (Kiev, 1902), 116-17.

6 Oleg Viktorovich Anisimov, Rossiia i Napoleon III. Bor'ba za Sviatye mesta Palestiny [Russia and Napoleon III: the struggle for the holy places in Palestine] (Moscow: Indrik, 2014).

7 AVPRI, col. 161, St. Petersburg Main Archive, IV-2, cat. 119. 1858-6o. No. 22. F. 17r. (translated from French).

8 Ibid., fol. $20 v$ (translated from French).

9 Ibid., fol. 18r (translated from French). 
In St. Petersburg, members of the ROPIT insisted on the establishment of an independent consulate in Jerusalem. The proposal was first presented by Boris Pavlovich Mansurov as part of the Jerusalem Project of Russia, in December 1857. Mansurov had the support of Grand Duke Konstantin Nikolaevich, the tsar's brother. ${ }^{10}$ The tsar approved the opening of the consulate on the condition that a program to improve the living conditions of Russian pilgrims in the Holy Land would be implemented in early February 1858. The task of organizing the project, which included choosing the first Russian consul, was commissioned to the ROPIT, and to Mansurov in particular. The ROPIT agreed to subsidize the new consulate and to pay for the travel expenses of its personnel from Russia to Jerusalem. During the first year, the ROPIT paid all the expenses of the consulate. ${ }^{11}$

Mansurov proposed Vladimir Ippolitovich Dorgobuzhinov, a colleague from the Naval Ministry, for the position of consul. On February 10, 1858, in a private message to Butenev, Mansurov requested the return of Marabutti from Jerusalem to Jaffa. ${ }^{12}$ Even though the responsibility of establishing the consulate was given to Mansurov, the consulate was officially subordinate to the Russian Embassy in Constantinople. On the commission of Gorchakov, Butenev compiled a formal instruction for Dorgobuzhinov. He stressed that the main aim of the consulate in Jerusalem was:

to save our bishop both from police surveillance over the arriving Russian worshippers and from direct contacts with Turkish authorities and foreign consuls in Jerusalem. These exchanges occur not only on completely nonreligious issues but also on spiritual affairs, that, as it often happens, demand explanations or negotiations with these authorities. Thus, we ask that the consulate deal with surveillance of our worshippers and that it manage our relations with the Turkish administration as well as with the consuls of other foreign states. ${ }^{13}$

10 Mansurov described the plan of actions in a secret note published in the printing office of the Naval Ministry without the author's name and without a title, in thirty copies. See Boris Pavlovich Mansurov, Pravoslavnye poklonnikiv Palestine [Orthodox pilgrims in Palestine] (St. Petersburg, 1857), 209. AVPRI, col. 161. St. Petersburg Main Archive. IV-2. cat. 119. 1858-6o. no. 22, fol. 64v. Message from B. P. Mansurov to the envoy in Constantinople A. B. Lobanov-Rostovskii.

12 AVPRI, col. 161. St. Petersburg Main Archive. IV-2. col. 119, 1858-60, no. 22, fol. 21v. (translated from French).

13 "A. P. Butenev's instruction for the Jerusalem consul, V. I. Dorgobuzhinov," in Lisovoi, Rossiia $v$ Sviatoi Zemle vol. 1. (2015), 220. 
Thus, the consulate was to fulfill functions that were previously reserved for the head of the REM and, prior to that, (especially for the surveillance of Russian pilgrims), for the Greek Orthodox Patriarchate. However, the abovementioned instruction subordinated the consul to Bishop Kirill.

Mansurov outlined the acquisition of land lots in Jerusalem and in other places visited by Russian pilgrims as well as the construction of infrastructure on those lots as the primary focus for the new consul. For these activities, the consul was subordinate to the Palestine Committee in St. Petersburg. According to the staff list of the Ministry of Foreign Affairs, the first Russian Consulate in Jerusalem involved two people: a consul and a secretary. In reality, the situation was quite different. By mid-January 1859 , there were many more people serving there, including Consul V. I. Dorgobuzhinov, Secretary A. K. Krivoshein, one member of the chancellery (or scribe) P. D. Levitov, one dragoman (interpreter), M. O. Shakhashiri, recommended to Mansurov by the consul general in Beirut, Mukhin, and two consular Muslim guards, kawas, designated among the local people.

While the consulate was being established, French diplomats worked together with the Sublime Porte for the reconstruction of the cupola of the Holy Sepulchre. Soon after Dorgobuzhinov arrived in Constantinople, in early August 1858, the French ambassador, Édouard Thouvenel, invited him to a formal private dinner during which they discussed the progress of the work on the cupola. Butenev described that conversation in a message to Minister Gorchakov, praising the behavior of the new consul. ${ }^{14}$ Considering this message, we may claim that Dorgobuzhinov had been well prepared before his visit to Jerusalem. He was well informed and able to appeal to the interests of both the Greeks and the Russians. At the same time, he found points of compromise for further cooperation with the French.

This contributed to the strengthening of relations between Russia and France in the 1850 s after the Crimean War, and Napoleon III expressed interest in joint projects to consolidate the relationship between the two countries. It became clear that Kyrillos II's request for the establishment of the Russian consul to Jerusalem was a positive move. The patriarch realized that France would not create conflict with the Russians, and therefore, the Russian presence would be much more useful for the Greek Orthodox Patriarchate in Jerusalem than it had been previously.

14 Ibid., $3^{6-39}$ (translated from French). 


\section{The Russian Consul in Jerusalem: In the Interstices of Wars and Counterpowers}

From the inauguration of the consulate in 1858 until the First World War, fifteen consuls and administrators served in Jerusalem. ${ }^{15}$ For many of them, their service in Jerusalem proved challenging and for some, detrimental to their careers. Some fell sick and even died because of the harsh climate and poor living conditions. Dorgobuzhinov suffered a serious ear infection that almost left him deaf. The success of his diplomatic career suffered as a result of the conflict that he had with Bishop Kirill. His successor, K. A. Sokolov (186o-62), spent two winters in Jerusalem. He fell sick and died in Constantinople without medical treatment. Consul A. N. Kartsov (1863-67) caught smallpox in Jerusalem. Consul V. F. Kozhevnikov spent fifteen years in Jerusalem overall; he died suddenly due to an acute lung condition on Holy Thursday in March $1885 .{ }^{16}$ He left his adopted son, a local Arab boy, in Jerusalem. N. N. Illarionov had to ask the Ministry of Foreign Affairs to transfer him to another place because of a conflict with the head of the REM, Archimandrite Antonin (Kapustin). ${ }^{17}$ Consul D. N. Bukharov also had a conflict with Archimandrite Antonin (Kapustin) and was removed following orders from Grand Duke Sergei Alexandrovich, Chairman of the Imperial Orthodox Palestinian Society. ${ }^{18}$

15 Vladimir Ippolitovich Dorgobuzhinov (consulate administrator, 1858-60), Konstantin Alexandrovich Sokolov (consul, 1860-62), Nikolai Fedorovich Gladkoy (consulate administrator, 1862), Andrei Nikolaevich Kartsov (consul, 1862-67), Trofim Pavlovich Yuzefovich (consulate administrator, 1864 and 1874-75), Vassilii Fedorovich Kozhevnikov (consul, 1867-76; consul general, 1879-85), Nikolai Nikolaevich Illarionov (consul, 1876-79), Semen Mikhailovich Dmitrevskii (consulate administrator, 1885), Alexander Alexandrovich Guirs (consulate administrator, 1885-86), Dmitrii Nikolaevich Bukharov (consul, 188688), Aleksei Petrovich Beliaev (consulate administrator, 1888-89), Victor Alexandrovich Maksimov (consulate administrator, 1883-84, consul, 1889-91), Sergei Vasilievich Arsen'ev (consul general, 1891-97), Alexander Gavrilovich Yakovlev (consulate general administrator, 1894-95; consul general, 1897-07), and Aleksei Fedorovich Kruglov (consul general, 1908-14).

16 Not only Russian diplomats suffered from the severe living conditions in Jerusalem. Kozhevnikov noted that, on May 16, 1883, the French consul, Langlais, died suddenly from a heart attack. AVPRI, col. 180. Constantinople embassy. cat. 517/2. no. 1828, fol. 114v.

17 Lucien J. Frary, "Russian Missions to the Orthodox East: Antonin Kapustin (1817-1894) and his World," Russian History 40, no. 1 (2013).

18 Together with the opening of its diplomatic mission in Palestine, the Russian government arranged the everyday life of Russian pilgrims. The construction of pilgrims' houses in Palestine was supervised by the Palestinian Committee (1859), headed by Grand Duke Konstantin Nikolaevich, later transformed into the Palestinian Commission (1864). One 
The development of relations with the Turkish authorities and European colleagues relied heavily on the character of the individual consuls. We know, for instance, that in 1874 , the appointment of Kozhevnikov to Jerusalem was delayed because the Ambassador in Constantinople, Nikolai Pavlovich Ignat'ev, considered that the neutral disposition of the consulate's administrator, Yuzefovich, made him a better candidate to organize the elections of a new patriarch:

Personal collisions of Mr. Kozhevnikov with some of foreign consuls, with the head of our Ecclesiastical Mission, with many members of the local Orthodox clergy and with the most important persons among the Greek party, particularly his prior long-lasting enmity with Palestinian Governor 'Ali Bey, started in Tyrnovo and were renewed some time ago in Jerusalem. In the case of his return to the place of his service at the moment of crisis, this will only stir up passions and damage the success of the program, which is currently being developed by Mr. Yuzefovich. ${ }^{19}$

However, the Jerusalem consul was still in a delicate position because he did not have the same level of freedom and authority that most Russian consuls had in other places. This was because three other representatives of the Russian authorities also existed in Jerusalem: the Russian Ecclesiastical Mission, the Palestinian Committee (later, the Palestinian Commission at the Asian Department of the Ministry of Foreign Affairs), and the Imperial Orthodox Palestinian Society. Interactions between them were neither easy nor successful. A consul often served as a mediator in St. Petersburg's attempts to instill peace and order among the Russian delegates in Jerusalem.

The history of the Russian Consulate in Jerusalem can be divided into several stages. The initial period $\left(185^{8-62}\right)$ was connected with the names of Mansurov, Dorgobuzhinov, and Sokolov, and with the activity of the Palestinian Committee. During this time, the main lots were purchased and the construction of the first Russian churches and residences in Jerusalem began.

of the key figures of these institutions was B. P. Mansurov. In 1882, the Imperial Orthodox Palestinian Society was established to replace these institutions; a brother of Tsar Alexander III, Grand Duke Sergei Alexandrovich, headed it. It was a public organization for the benefit of Russian pilgrims and supported Orthodoxy in the Holy Land. It also sponsored research work.

19 AVPri, col. 161/1 St. Petersburg Main Archive, V-A2, cat. 181/2. Political reports no. 436, 1875 , fol. $7 \mathrm{~V}-9 \mathrm{v}$. Message of the Constantinople ambassador, N. P. Ignat'ev, to the director of the Asian Department of the Ministry of Foreign Affairs, P. N. Stremoukhov, March 31, 1875 . 
The second period (1862-76) may be considered the golden age of Russian diplomacy in the Orthodox East, with Constantinople Ambassador Ignat'ev as one of its leading figures. He directed the actions of all Russian representatives in the Holy City with a firm hand, and ensured their work was well-coordinated and efficient. During the Russian-Turkish War (1877-78), the activity of the consulate was suspended. Over the following two years, the Ministry of Foreign Affairs made attempts to define the relations between the consulate and the REM, and to enlist the responsibilities of the consulate.

The third period (1881-1914) was the golden age of the Imperial Orthodox Palestinian Society. The consulate and the REM had to follow the lead of the Society, which was a public institution but, in fact, expressed government interests.

The everyday activity of the consulate was devoted to Russian subjects merchants, monks, permanent residents, travelers, and numerous pilgrims. Diplomats arranged money and documents for remittance. They controlled their compatriots and provided meetings for dignitaries. Throughout their work, they had the constant support of the Greek Orthodox clergy and the local Greek Orthodox Arabs.

For the period from the mid-nineteenth century until World War I, the documents of the consulate convey that there were several cases that attracted the attention of Russian diplomats in Jerusalem. In the first half of the 186os, the Russian and French governments represented the interests of the Greek and Catholic clergy in the Holy Land, respectively. They were both involved in reconstructing the cupola of the Holy Sepulchre. The Russian and French architects M. I. Eppinger and C. Mauss supervised this work. All technical and decorative characteristics of the project were endorsed in the consulates in Jerusalem, and then in the embassies in Constantinople. Finally, the ministries in Paris and Petersburg approved the project. ${ }^{20}$

In 1872 , following a conflict with the Greek clergy in Jerusalem, Patriarch Kyrillos II was displaced. The Russian consulate tried to return the patriarch to the Jerusalem See, and also made efforts to soften and neutralize the anti-Russian orientation of the Greek Orthodox Synod. Russian diplomats contributed to the reconciliation between the Greek Orthodox Arab

20 On the restoration of the cupola, see Anisimov, Rossiia $i$ Napoleon III; Anisimov, "Frantsuzskii konsul Edmond de Barrère i problema remonta rotondy Sviatogo Groba v Ierusalime, arkhivnye dokumenty. Publikatsia Olega Anisimova" [French consul Edmond de Barrère and the problem of the reconstruction of the Holy Sepulchre's dome: documents from archives published by Oleg Viktorovich Anisimov], Ierusalimskii pravoslavnyi seminar 5 (2010). 
population, which did not accept the new patriarch or the Greek clergy. The Russians set a necessary condition for reconciliation: the replaced patriarch could no longer be pronounced schismatic. Documents on those events allow us to observe the process of Russian diplomacy on different levels. There were discrepancies between the instructions from Petersburg and Constantinople and the activity of Russian representatives on site in Jerusalem. Reports of the Russian consulate indicate that the German consul was involved in the replacement of Patriarch Kyrillos II.

Construction of Russian pilgrim and ecclesiastic buildings on the lots bought by the head of the REM, Archimandrite Antonin (Kapustin), began in the late 186os. In Jerusalem, among those lots were the Siloam Monolith (the Tomb of the Pharaoh's Daughter), a lot on the Mount of Olives, and a third lot in 'Ayn Karim. The lots were acquired under the name of the dragoman of the REM, the Ottoman subject Ya'qub Khalebi. Documents on these transactions reflect the legal and habitual practice of the Ottoman Empire on land property rights. For example, when the Russian Pilgrims' Hospital was opened in 1863, the Russian Consulate obtained documents on the sanitary situation in Palestine. As such, the daily life of pilgrims was interpreted from a new point of view.

During the Russian-Turkish War of 1877-78, the consulate was evacuated, and the archives and the buildings were placed under the protection of the Prussian consul:

In the case of a possible break with Turkey, who would take over the management of the buildings - the monastery [the Patriarchate of Jerusalem], or the Spanish Consul? Are there obstacles we might face when we attempt to receive our buildings and property back from the monastery after our return? It seems better to seek protection from the Spanish Consul, from whom we cannot expect any claims, and whose protection might be more efficient than that of the monastery, which won't dare to fight for Russian possessions against the Turkish rage. Naturally, the best way would be to pass everything to the German Consul, but Germany may break relations with Turkey simultaneously with us. ${ }^{21}$

After the war, the consulate was active in the affairs of Russian property in Palestine, and remained involved in the matters of the Greek Orthodox

21 AVPRI, col. 180, Constantinople embassy, cat. 517/2, no. 780, fol. $26 \mathrm{v}-$ r. Instruction of the attorney in Constantinople, E. P. Novikov, to the Jerusalem consul, N. N. Illarionov, October 13,1876 . 
Patriarchate (for instance, the election of Patriarch Damianos in 1897). The activity of charitable institutions and schools founded by the Palestinian Society also demanded much attention. Moreover, the position of Jews arriving in the Holy Land, and their future, became a topic of discussion.

\section{In Search of the Lost Archives of the Jerusalem Consulate}

Since 1879 , the consulate in Jerusalem was headed by a consul general. In 1891, the consulate obtained the status of consulate general. The official Russian presence in Jerusalem was maintained until World War I, when Russia and the Ottoman Empire found themselves on opposite sides. When the Great War began, Russian diplomats left Jerusalem for Egypt. The archives were lost during this period. The Ottomans may have plundered the archives of the consulate general in 1916. This hypothesis is supported by a note from the American consul, who protected Russian property in the Holy Land from $1915 .{ }^{22}$ Russian constructions located along the walls of the Old Town were surrounded by an enclosure. They were well-equipped with sufficient stores and provisions. The Ottomans used the Russian settlement for their own garrison; breaking diplomatic laws, they plundered the Russian compound and put it out of commission. In 1917, having driven the Ottoman troops out of Jerusalem, the British took over the Russian edifices, including the consulate building. For a long time, they served as a citadel and a center of British military administration in Palestine.

There is not sign of the diplomatic documents that were lost in 1917, or later in the British Mandate period. The disappearance of such a large quantity of documents is strange, given that the archive of the REM, located in the same building complex, was largely preserved. It is possible that the archive was temporarily relocated to Russian monasteries - to Ayn Karim or the Mount of Olives - which were never occupied by Ottoman or British troops.

The library and documents kept at the St. Sergios town residence of the Imperial Orthodox Palestinian Society also remained intact until the Six Days War in 1967. When the building was surrendered to Israeli tenants and a state protector was appointed, the documents were partly plundered. The loss of the documents of the consulate in Jerusalem, however, was not permanent. Below, we will examine the ways these documents circulated in the Russian Ministry of Foreign Affairs, and particularly in the consulate in Jerusalem. 
The consulate was subordinate to the Russian embassy in Constantinople, which was controlled by the Asian Department of the Ministry of Foreign Affairs, in existence since 1819. The Asian Department was the only one of three departments of the Ministry of Foreign Affairs created on a geographical principle. It focused on Oriental policy, on the affairs of Russian subjects in the East, and on the training of translators and dragomans for Russian missions in the region. The Asian Department (renamed the First Department in 1897) consisted of two sections: the Far East and the Middle East. In the Middle Eastern section, there was a political desk, which worked on enciphering and deciphering telegrams. It also worked on Slavic, Greek, and Turkish desks (later, Persian and other desks were formed). Two or three people worked at each desk.

The consulate in Jerusalem, like any other diplomatic establishment, had incoming and outgoing documents. Incoming papers comprised two different groups: documents from official institutions and private documents from individuals. We can categorize incoming documents into those sent from inside or outside Palestine. Incoming documents from Russian state institutions, such as the embassy in Constantinople, the consulate general in Beirut, and the Ministry of Foreign Affairs in St. Petersburg, were kept in copy. This was a procedure that was compulsory in any formal correspondence. Copies of documents sent to the Russian Consulate from the Patriarchate of Jerusalem and from other Ottoman and European institutions in Palestine were preserved in the archives of those organizations.

There is another problem regarding private messages and addresses sent to the consulate. We cannot estimate their quantity. Sometimes, such documents - whether copies or originals - were resent from the consulate to the embassy or even to the Asian Department. One can find, for instance, messages from the Patriarch of Jerusalem, ${ }^{23}$ members of the Synod of Jerusalem, ${ }^{24}$

23 AVPRI, col. 161, St. Petersburg Main Archive, II-9, cat. 46, 1840, no. 15. pt. 1, fol. 6o6v-9v. In December 1866, Patriarch Kyrillos wrote to the Constantinople envoy, A. B. LobanovRostovskii, with an appeal to reject the transfer of Consul A. N. Kartsov, who had developed good relations with the Patriarchate of Jerusalem. St. Petersburg did not agree to the patriarch's request. See message, December 22, 1866.

24 AVPRI, col. 161/1, St. Petersburg Main Archive, V-A2, cat. 181/2, political reports, no. 433, 1873 , fol. $2 \mathrm{v}-3 \mathrm{v}$. See, for instance, the appeal of the Synod of Jerusalem to the Orthodox community of Bethlehem on the excommunication of Patriarch Kyrillos, November 8, 1872 . 
Greek and Arab priests, ${ }^{25}$ Arab and Jewish communities, ${ }^{26}$ as attachments to consular reports or to messages sent to the Ministry of Foreign Affairs from the embassy in Constantinople. Incoming documents were kept as drafts or copies among the documents of the embassy in Constantinople, the Asian Department, and the chancellery of the Ministry of Foreign Affairs.

Outgoing documents consisted of reports and telegrams from consuls to the embassy and to the Ministry of Foreign Affairs, as well as private and semiformal (called "confidential") messages to various officials of the Ministry of Foreign Affairs, both in Constantinople and in St. Petersburg. Consuls often sent copies of their reports addressed to the embassy in Constantinople to the Asian Department. Originals of outgoing documents are preserved in the corresponding collections of the archive of the Ministry of Foreign Affairs.

During the nineteenth century, the Ministry of Foreign Affairs possessed three different archives. There was the St. Petersburg Main Archive of the Ministry of Foreign Affairs, the State Archive of the Ministry of Foreign Affairs in St. Petersburg, and the Moscow Main Archive of the Ministry of Foreign Affairs. The main documents on Russian history until the early nineteenth century were kept in the older Moscow Archive (founded on the base of the Collegium of Foreign Affairs in 1724). Documents from later decades were passed to the Russian State Archive of Ancient Acts (RGADA). In the St. Petersburg State archive (also called the State Archive of the Russian Empire, made up of documents of nondiplomatic character from the Ministry of Foreign Affairs in 1834), materials on the tsars and their family, notorious criminal trials, industry, culture, and history of peoples of Russia were kept. In 1864, the State Archive of the Russian Empire was united with the St. Petersburg Archive of the Ministry of Foreign Affairs. Later, its collections were passed to the RGADA.

The main documents on the current activity of the Ministry of Foreign Affairs, including those on the activity of the consulate in Jerusalem, were kept in the St. Petersburg Main Archive. These materials were passed on to the

25 AVPRI, col. 161/1, St. Petersburg Main Archive, V-A2, cat. 181/2, political reports, no. 433, 1873, fol. 39v-49r. In March 1873, for instance, Priest Iskhak, from the settlement of Beit Jala, alleged to the Russian Consulate and the REM that Greek clergymen had instigated the local Turkish authorities to arrest him because of his refusal to recognize the newly elected Patriarch Prokopios.

26 AVPRI, col. 180, Constantinople embassy, cat. 517/2, no. 1809, fol. 12v-13v. See, for instance, a message from the head of the Jewish community to Consul A. N. Kartsov, December 25, 1863, about French travelers exporting Judaic marble coffins and gravestones. 
Archive of Foreign Policy of the Russian Empire (AVPRI). Its collections were organized based on document provenance and subject.

In the process of publishing the formal correspondence of the Russian consuls in Jerusalem from $1858-80$ during the reign of Tsar Alexander II, ${ }^{27}$ we revealed the main corpus of originals, drafts, and copies of the documents in question at the (AVPRI). The corpus was essentially identical to the archive of the Russian Consulate in Jerusalem for the selected period. The following is a description of the collections of the AVPRI. The collections contain documents on the activity of the Russian Consulate in Jerusalem and on the Russian presence in Palestine.

Collection 133 (Chancellery of the Ministry of Foreign Affairs), 1797-1917. 28837 doc. Catalogue 469, 1830-1869; Catalogue 470, 1870-1917.

Documents are classified by year. They include incoming and outgoing correspondence from the embassy in Constantinople on the affairs in Jerusalem, original messages from Russian ambassadors and envoys in foreign states; their letters, reports, telegrams, and instructions, and notes, and telegrams from the Ministry of Foreign Affairs.

Collection 180 (Embassy in Constantinople), 1800-1914, 12519 doc.

Catalogue 517/2, 1856-1914.

The collection contains the following materials: tsars' rescripts, relations from envoys in Constantinople, correspondence between the Ministry of Foreign Affairs and the mission (or embassy, since 1867), correspondence between the mission and Ottoman authorities, diplomatic corps in Constantinople, Russian consular offices in the Ottoman Empire (including Jerusalem), correspondence with Russian envoys in other countries, messages on ecclesiastic matters, on Russian property in the Ottoman Empire, on the Russian-Turkish wars, on peace treaties, on the situation in the Balkans, on the policy of the Great Powers in the Ottoman Empire, international conferences, directives from the embassy in Constantinople to Russian consulates in the Ottoman Empire, and correspondence with private persons. The collection contains thematic files on correspondence between ambassadors and the consulate in

27 Graf N.P. Ignat'ev i Pravoslavnyi Vostok: dokumenty, perepiska, vospominania [Count N. P. Ignat'ev and the Christian Orient: documents, correspondence, memoirs], vol. 2 (Moscow: Indrik, forthcoming in 2018). 
Jerusalem over several years. In addition, there are many thematic files on various events in Jerusalem and Palestine. ${ }^{28}$

Collection 149 (Turkish desk), 1818-1917. 11967 doc.

Catalogue 502/1, Catalogue 502/2.

This collection contains documents with data about the consulates in Beirut and in Constantinople, consular regulations in the East, consular jurisdiction, consulate personnel, quarantines, epidemic diseases, sanitary council, pilgrims, hajj, grasshopper plague, earthquakes, capturing boats, contraband, research works and excavations, Jews, private persons abroad, military duty, vagrants, deserters, school manuals, taxes in Turkey, courts, and jails. Among the documents of this section of the Asian Department, the most important ones for the activity of the Russian Consulate are documents on the preparation and arranging of expeditions and archaeological excavations in Palestine, as well as documents on Russian pilgrims in Jerusalem.

Collection 142 (Greek desk), 1825-1917. 6733 doc.

Catalogue 497.

There are documents on nonpolitical affairs taken from the Second Political Department connecting Greece, Greek subjects, and the activity of Russian consular institutions in Greece, as well as documents on Palestine reflecting the position of the churches, sanitary conditions, court and police affairs, and the history of the Patriarchate of Jerusalem. This collection also contains magazines, documents of the Palestinian Committee, and the Palestinian Commission at the Asian Department, which arranged the acquisition of land lots, the construction of town residences in Jerusalem, and dealt with the common life of pilgrims.

Collection 161 (St. Petersburg Main Archive), 180o-1905. 91686 doc., in general, 173 catalogues.

There are materials of the former State Main and St. Petersburg Main Archive. The documents were gathered by the central apparatus of the Ministry of Foreign Affairs and by the Collegium of Foreign Affairs, consular and diplomatic offices abroad. The majority of the documents are from $1800-85$. The collection is divided into five artificial ranks, which are divided into groups. The documents are classified according to the following topics.

28 For instance, a trip of Russian grand dukes to Palestine (1881, 1888), election of Patriarch Damianos (1897) and so on. 
In the First Series, there is a complex group of documents connected to Jerusalem. A significant section of this group is unavailable to researchers. Topics include:

I-1 catalogue 12. Reports on the affairs in Turkey, Greece, Egypt, and Serbia (1822-79).

I-1 catalogue 19. Highly confirmed projects of messages on the affairs in the Middle East (1816-55).

I-9 catalogue 8. Materials on commissioning diplomatic envoys, information on events in Turkey, materials on the clergy, and ecclesiastic affairs. Notes and memoirs. Materials on railway construction and the telegraph (1774-1905).

I-1o catalogue 28. Printed copies of agreements, conventions, treatises (particularly with Turkey).

Many documents on Palestine are kept in the Second Series (1763-190o), including:

II-3 catalogue 34. Russian trade relations with countries of the Middle East, reports of consulates and the general situation in the consulates (1783-1869).

II-3 catalogue 35. Russian trade relations with countries of the Middle East, reports of consulates and the general situation in the consulates (1869-96). II-9 catalogue 46. Spiritual affairs, monastic properties, Russian pilgrims in Palestine.

II-9 catalogue 83. The Ecclesiastical Mission in Jerusalem.

II-10 catalogue 49. Professor Pomialovsky's trip to Palestine (1864-91).

IV-1o catalogue 129. Private messages of the administrator of the consulate in Jerusalem on the situation in Jerusalem (1801-1879).

IV-16 catalogue 134. On the protection of rights of Orthodox clergy in the East by the Russian government.

IV-18 catalogue 137. Documents related to a water-supply system project in Jerusalem.

Collection 161/1 (Political reports on the Middle East and Central Asia) St. Petersburg Main Archive, 1802-87. RankV-A ${ }_{2} 1203$ doc., catalogue 181/2.

The collection contains selected reports on the Middle East, including political reports from Russian consuls in Jerusalem. This collection is divided into numerous series and catalogues, and includes many thematic files on events in Jerusalem. 
Collection 161/3 (Political Department of the St. Petersburg Main Archive), 180685. 261 doc.

Catalogue 233.

There are documents of special political importance (with a stamp specifying "eternal storage"), notes and references on various issues, particularly on ecclesiastic matters in the East and the situation in Jerusalem.

Collection 337/1. Palestinian Commission, 1865-89. 4 doc.

Catalogue I (765).

Registers of incoming and outgoing papers, journals of sessions of the Palestinian Commission.

Collection 337/2 (Russian Imperial Orthodox Palestinian Society), 1844-1928.

Catalogue $873 / 1-13$

The collection contains numerous documents of the Russian Imperial Orthodox Palestinian Society, and its predecessors - the Palestinian Commission at the Asian Department, (Catalogue 765) on activities in the Holy Land and in Jerusalem - on Russian construction projects in Jerusalem, manuscripts on travels to Palestine, on the common life of pilgrims, and on the administrative structure of Palestine.

Catalogue 1. (1879-1918), 778 doc.

There is material on the Russian Imperial Orthodox Palestinian Society, correspondence with administrators of the town residence, material on schools and ambulances in Palestine, material on the trips of members of the tsar's family to the Holy Places, on arrival of crews from Russian boats to Jerusalem, reports of medical institutions, personnel at the teaching institutions of the Russian Imperial Orthodox Palestinian Society in Palestine, and correspondence with consulates and the Ecclesiastical Mission.

Catalogue 9. (1897), 4 doc.

Plans of constructions and photographs of churches and town residences in Jerusalem.

Collection 208. Consulate in Beirut (Lebanon), 1820-1914. 686 doc.

Catalogue 819.

The Russian Consulate in Lebanon was initially located in the city of Jaffa. In 1839, it was transferred to Beirut. In this collection, there is correspondence between the consulate and the mission (embassy in Constantinople), the 
consulate general in Alexandria (the consulate in Beirut was subordinate to it until the 1840s), correspondence with vice-consulates, and agencies subordinated to the consulate in Beirut (including the Jerusalem consulate), material on trade, sea travel, railways, ecclesiastic matters (propaganda, clergy, etc.), pilgrims, the Russian Imperial Orthodox Palestinian Society, educative institutions, court cases, sanitary issues, military duty, exhibitions, financial matters, magazines, and books.

Collection 313. "Vice-consulate in Jaffa" (Turkey). 1820-66. 5 doc.

Catalogue 823 .

There are instructions from the Ministry of Foreign Affairs, the mission in Constantinople, and correspondence with consulates general in Egypt.

Topics in the archives between local and central levels and between the religious and the profane

In the AVPRI collections, there are numerous documents with data on the following broad topics:

Russian policy in Palestine, communication with local and central Ottoman authorities

The Ambassador in Constantinople evaluated the work of his subordinates in Palestine based on their interactions with Ottoman officials. Sometimes, meetings with the grand vizier and other senior officials in the capital could influence instructions sent by the Sublime Porte and could bring change in Jerusalem. In 1869, for instance, Constantinople Ambassador N. P. Ignat'ev informed the Jerusalem consul, V. F. Kozhevnikov, of the following:

Because of the commissioning of Kiamil Bey, the first secretary of the local Ministry of Foreign Affairs, to the position of Governor of Jerusalem, I suppose it is worth familiarizing you in advance, in general, with the character and the direction of this person, with whom you are to keep direct official relations. Kiamil Bey served in the diplomatic field and was in the Turkish mission in St. Petersburg. He was Chairman of the Commission on the matter of the expropriation of the ecclesiastic royal estate by the governments of Moldavia and Wallachia, and recently was the head of the department on spiritual affairs of various confessions in the Sublime Porte. Kiamil Bey is therefore closely acquainted with the situation in Jerusalem, and he knows all details about the Holy Places. Serving in the Sublime Porte, he did not miss a chance to be compliant, 
and demonstrated good decision-making capabilities. During our latest meeting, I did not fail to attract his attention to the necessity - for the sake of the interests of the Porte itself - of keeping kind relations with the Consulate entrusted to you, as well as to protecting the principle of the Status Quo in the process of renovating objects or monuments in Jerusalem, preventing possibly growing controversial questions, and solving problems on the spot. You are, Sir, to make all efforts to support Kiamil Bey in his current mood and to prevent any Western influence from overcoming this well-disposed but weak-willed Governor of Jerusalem..$^{29}$

\section{Aspects of Daily Life in Palestine}

Russian consuls wrote to St. Petersburg about the quantity of Turkish troops located in Palestine, about interrelations between Muslims and Christians, conflicts among numerous Christian confessions, Bedouin rebellions, epidemics, etc. In August 1860, Consul Sokolov wrote to Envoy A. B. Lobanov-Rostovsky in Constantinople:

Christian dwellers of the Holy City and its surroundings were stricken with panic following rumors of a riot. Although such suppositions had no grounds, and the behavior of Muslims was not especially suspicious, families have not gone out for several days. The clergy took measures to save treasures kept in various monasteries and churches. The Governor of Jerusalem, Sureyya Pasha, had at his disposal only one infantry battalion and few ordinances located in the citadel. He ordered to place guards at the main bazaars and streets and stationed commissioning officers to watch the order everywhere. Then he invited the most influential Muslims and declared that he would not allow any disturbances and would severely punish responsible persons if anything happened. That measure had a beneficial influence on the mood of local dwellers. News of the arrival of Fuad Pasha with his troops to Beirut somewhat soothed the fears of the Christian clergy. ${ }^{30}$

29 AVPRI, col. 180, Constantinople embassy, cat. 517/2, no. 1814, fol. 107v-r. Instruction from the Constantinople ambassador, N. P. Ignat'ev, to the Jerusalem consul, V. F. Kozhevnikov, September 24, 1869 .

30 AVPRI, col. 18o, Constantinople embassy, cat. 517/2, no. 1805 , fol. $45 \mathrm{v}-\mathrm{r}$, $48 \mathrm{v}-\mathrm{r}$. Report from the Jerusalem consul, K. A. Sokolov, to the Constantinople envoy, A. B. LobanovRostovskii, July 25/August 6, 1860. 
In March 1877, Consul N. N. Illarionov informed the councilor of the embassy in Constantinople, A. I. Nelidov, of the following:

At the end of the previous week, at some hours' distance from Hebron at Dura, there was a bloody clash because of the property rights to a land lot between two Bedouin tribes with the participation of some Muslim dwellers of that place. The clash was quite serious, because up to 100 people were reported to be murdered. Given the usual feuding here, new clashes could easily happen again, not only between Bedouins, but also among settlers. Settlers indeed number among the murdered. Clashes with Bedouins happen here from time to time, and they serve as a quite convenient case for persons sent by the governor to remedy the situation, and for the pasha himself. Often such disturbances between Bedouins are aroused by interested persons. It is said that the events happened at Hebron may be result of the activity of supporters of the mutessarif of Jerusalem, Faik Bey. This could give him the chance to return soon to Jerusalem from Damascus, where he had been called because of a claim against him. ${ }^{31}$

\section{Interactions between Russian and European Diplomats in the Holy Land}

Protecting the interests of Catholics and Orthodox Christians in Palestine was one of the missions of Russian and French diplomats. They were regularly involved in conflicts connected with property rights or certain privileges in churches of the Holy Land. Visits of dignitaries to Jerusalem and joint efforts in cases of epidemic diseases also called upon the presence of diplomats. Thus, in November 1871, Consul V. F. Kozhevnikov sent the following circular message to members of the diplomatic corps in Jerusalem:

Our agent in Jaffa just has informed me about four recent cases of cholera in Saint Jean d'Acre; two of them led to death. Because the epidemic may manifest itself in Jaffa or even in Jerusalem, it seems reasonable and cautious to have local authorities take measures in order to prevent the spread of the disease. I ask you, my dear colleague, for your benevolent

31 AVPRI, col. 180, Constantinople embassy, cat. 517/2, no. 1822, fol. 14V-15v. Report from Consul N. N. Illarionov to the Constantinople embassy councilor, A. I. Nelidov, March 4, 1877 . 
assistance, asking you to be so kind and inform me about a possible collective effort which could provide for Your Excellency's services and the mastery of foreign medics living in Jerusalem. ${ }^{32}$

\section{Interaction between Russia and the Patriarchate of Jerusalem and with Other Eastern Churches}

Russia provided material and political support for Eastern Orthodox churches. Foremost among these was the Patriarchate of Jerusalem. The Russian government kept a close watch on church incomes received by Eastern clergy from estates in Bessarabia. In September 1867, Constantinople Ambassador N. P. Ignat'ev informed the consul in Jerusalem, V. F. Kozhevnikov, of the appointment of a new archbishop of Sinai:

The Imperial Embassy cannot recognize the consecration of the new archbishop as final and real until he is recognized in this new rank by patriarchs and the Holy Synod. Until then, the Embassy finds impossible to take into account the aforesaid petition by Patriarch Kyrillos. Possessing the right and keeping the moral obligation to observe the use of income from Sinaitic properties in Russia, the Embassy treats as necessary to solicit the sequestering of this income until the question of the correctness and appropriateness of the election of the new archbishop is cleared, and until we receive enough guarantees of the rational and correct usage of these moneys. ${ }^{33}$

On the other hand, the Russian government and St. Petersburg regularly observed how the rights of the Orthodox were protected in their disputes with Catholics and Armenians. In spring 1869, a fire in the Grotto of the Nativity in Bethlehem destroyed part of the decoration. The Russian consul was invited to mediate in squabbles between Orthodox and Catholic Christians regarding the restoration of icons and curtains. He tried to reach a compromise between the demands of the Latin clergy, supported by the administrator of the French Consulate, Sienkiewicz, and the demands of Patriarch of Jerusalem.

32 AVPRI, col. 161/1, St. Petersburg Main Archive, V-A2, cat. 181/2, political reports, no. 430, 1871 , fol. 108v-r. Copy of a circular from the Jerusalem consul, V. F. Kozhevnikov, to members of the consular corps in Jerusalem, November $15 / 27,1871$.

33 AVPRI, col. 18o, Constantinople embassy, cat. 517/2, no. 1812, fol. $73 \mathrm{v}-74$ r. Draft of an instruction from the Constantinople ambassador, N. P. Ignat'ev, to the Jerusalem consul, V. F. Kozhevnikov, September 28, 1867. 
The problem was even discussed in the embassies in Constantinople, as well as by governments in St. Petersburg and Paris.

\section{The Diplomatic History of Russia, Interactions of the Consulate in Jerusalem with the Embassy in Constantinople, with the Ministry in St. Petersburg, and with the Vice-Consulate in Jaffa}

The diplomatic system was quite complicated, and could be easily disrupted by local circumstances and personal factors. In May 1860, the vice-consul in Jaffa, N. S. Marabutti, responded to Consul V. I. Dorgobuzhinov's reprimand about the delay in sending the pilgrim's passports:

Without a secretary, and having many duties, I am not always able to write and send you worshippers' passports in an hour or two before the departure of Russian mail after a steamship arrives, and I do not dare to send them with foreign mail, not knowing to whose account the sending costs could be put; as well as I cannot use "departure of worshippers' caravans" for sending passports, which I should organize by myself, as you, perhaps, do, Sir, in Jerusalem when they return to Jaffa. ${ }^{34}$

\section{Daily Life and Habits of Russian Pilgrims}

Material from the consulate gives us statistical data on pilgrims, their accommodations, and interactions inside the groups and with the Greek clergy. There is also information on steamships used by worshippers. In September 1866, for instance, Embassy Secretary Vasilevskii wrote in a private message to the Constantinople ambassador, N. P. Ignat'ev, about the difficult situation of Russian pilgrims who had returned from Jerusalem to Jaffa and planned to travel home but the Russian steamship was delayed:

A group of 14 worshippers have come recently from Jerusalem to Jaffa and want to return to Russia. They asked the Russian agent of the Society of the steamship line to trade their return tickets from Jaffa to Odessa, bought in an office in Odessa. They asked him to pay a refund for those tickets and to allow them to buy new tickets for a foreign steamship. The

34 AVPRI, col. 180, Constantinople embassy, cat. 517/2, no. 1805, fol. 33r-34v. Copy of a message from the Russian vice-consul in Jaffa, N. S. Marabutti, to the Jerusalem consul, V. I. Dorgobuzhinov, May 22, 1860. 
agent of our steamship company, Mr. Marabutti, having no instruction for such a case from his bosses, refused the request of our worshippers. As a result, the 9 female worshippers from the general group of 14 worshippers, having no money for other tickets for a foreign steamship, stayed in Jaffa to wait for the Russian steamship. In their state of abject poverty, they had to beg for alms in the street, and are dying of starvation. ${ }^{35}$

The pilgrims were in a dire state. Unable to support themselves, they returned to Jerusalem and lived at the expense of the head of the REM, Archimandrite Antonin. The consulate asked the Ambassador to order the steamship company to give money for the return tickets.

\section{Conclusion}

Comprehensive analysis of archival documents of the Russian Consulate in Jerusalem allows us to examine certain questions about the influence of diplomats in that region, and encourages us to look at communication among the Russian Consulate in Jerusalem, European diplomats, Christian churches, and local Turkish authorities. The most important sphere of activity of the Russian Consulate in Jerusalem was ecclesiastic and diplomatic. The consulate shared its responsibilities with the Russian Ecclesiastical Mission, the Palestinian Commission, and, later, with the Imperial Orthodox Palestinian Society. If we are to use the Russian archives to study the history of Russian communities in Jerusalem and to study the realities of the daily life of the Holy City, we should pay particular attention to the materials of the Russian Synod, the Russian Ecclesiastical Mission in Jerusalem, the Palestinian Commission at the Asian Department, and the Imperial Orthodox Palestinian Society. These documents may elucidate the joint national project of the Russian Empire in the Holy Land, implemented there from 1857 to 1917.

35 AVPRI, col. 18o, Constantinople embassy, cat. 517/2, no. 1811, fol. 3V-r. Private message from A. Vasilievskii to N. P. Ignat'ev, September 15, 1866. 